\title{
An Overview of Flyrock and its Prediction in Surface Mine Blasting using Soft Computing Techniques
}

\author{
Vineeth BALAKRISHNAN ${ }^{1}$, Piyush RAI ${ }^{{ }^{*}}$ \\ ${ }^{1}$ Department of Mining Engineering, Indian Institute of Technology (BHU), Varanasi 221005, India

\begin{tabular}{lr} 
"Sorumlu Yazar/Corresponding Author & Derleme Makalesi/Review Article \\
E-mail: prai.min@itbhu.ac.in & Geliş Tarihi/Received: 23.08.2021 \\
Orcid ID: 0000-0002-3312-2392 & Kabul Tarihi/Accepted: 22.09.2021 \\
\hline
\end{tabular}

\begin{abstract}
The occurrence of flyrocks due to blasting has certainly gained tremendous attention by recent researchers as well as mine operators since time immemorial. With the increase in demand for the mineral and subsequent thrust on the surface mining operations, the mining projects are expanding their scale of operations. As such, not only the mines, but also the nearby inhabitants are endangered. So flyrock is one of the most hazardous side effects of blasting operation in surface mining. There are several empirical methods for predicting flying rocks. The poor performance of these different methods is due to the complexity and difficulty of rock analysis. The existence of various influential parameters and their unknown relationships are the main reasons for the inaccuracy of empirical models. In this light, the present paper gives an overview of state-of-art researches and their outcome in the area of control and prediction of flyrocks. The paper discusses the significant contribution of soft computing techniques in controlling and minimizing the flyrocks. Furthermore, it lays emphasis on scientific and categorical identification of most significant rock explosive and blasting design parameters in the prediction models to enhance their precision and universalization.
\end{abstract}

Keywords: Flyrocks, Safety, Prediction Models, Blasting

\section{Yapay Zeka Teknikleri Kullanılarak Yerüstü Maden Patlatmasında Kaya Fırlamaları ve Tahminine Genel Bir Bakış}

\begin{abstract}
ÖZET
Patlatma nedeniyle kaya firlamalarının oluşumu, çok eski zamanlardan beri maden operatörlerinin yanı sıra son araştırmacılar tarafından kesinlikle büyük ilgi görmüştür. Yüzey madencilik operasyonlarına yönelik mineral ve daha sonraki talep artışı madencilik projeleri operasyonlarının ölçeğini genişletiyor. Hal böyle olunca sadece madenler değil, çevredeki sakinler de tehlike altına giriyor. Öyle ki kaya firlamaları, yerüstü madenciliğinde patlatma işleminin en tehlikeli yan etkilerinden biridir. Kaya fırlamasını tahmin etmek için deneye dayalı birkaç yöntem vardır. $\mathrm{Bu}$ birbirinden farklı yöntemlerin düşük performansa sahip olması, kayaç analizinin karmaşıklığından ve zorluğundan kaynaklanmaktadır. Çeşitli etkili parametrelerin varlığı ve bunların bilinmeyen ilişkileri, deneye dayalı modellerin yanlışlığının ana nedenleridir. Bu 1şık altında, bu makale, kaya firlamalarının kontrolü ve tahmini alanındaki en son araştırmalara ve bunların sonuçlarına genel bir bakış sunmaktadır. Bu makale, yumuşak hesaplama tekniklerinin kaya fırlamalarını kontrol etme ve minimize etmede önemli katkısını tartışıyor. Ayrıca, kesinliklerini ve evrenselleşmelerini geliştirmek için tahmin modellerinde en önemli kaya patlayıcı ve patlatma tasarım parametrelerinin bilimsel ve kategorik olarak tanımlanmasına vurgu yapmaktadır.
\end{abstract}

Anahtar Kelimeler: Kaya Firlamaları, Güvenlik, Tahmin Modelleri, Patlatma

\section{Cite as;}

Balakrishnan, V., Rai, P. (2021). An Overview of Flyrock and its Prediction in Surface Mine Blasting using Soft Computing Techniques, Recep Tayyip Erdogan University Journal of Science and Engineering, 2(2), $105-119$. Doi: 10.53501/rteufemud.986903 


\section{Introduction}

The mining industry largely depends on blasting for rock excavation. It is the first and the most important operation in the mining production cycle. The main objective of rock fragmentation by blasting to break the maximum possible quantity of rock at a minimum cost with minimum damage to the environment (Kahriman et al., 2006; Uysal et al., 2013; Karadogan et al. 2014; Gorgulu et al., 2015; Kulekci and Alemdag, 2016). The materials that are blasted include ore, coal, overburden rocks, limestone, aggregates for construction industry and rocks in tunnelling operations etc. A precise application of engineering is essential in achieving the desired objectives of blasting. The blasting operation must ensure quality and quantity requirements of production, maximizing the overall economics of any mining operation. The damage to the environment by various nuisances must also be properly controlled for their minimization.

In any surface mines, the cycle of drilling and blasting operations comprises of drilling blast holes in a fixed pattern on the bench. The blast holes are charged with explosive and stemmed with stemming material. The blast holes are then fired using predetermined blast patterns and delay timing. The explosive action causes rock to fragment with variable throw and drop of the muckpiles, depending on the pattern and blasting designs. The fragmented rock is subsequently loaded and transported for further downstream operations.

In general, the fragmentation optimisation with safety, ease of loading, controlled throw, drop and scatter of fragments are the prime objectives in any blasting operation. The primary blast must be designed in such a manner that the resulting fragments require little or no secondary breakage. Large fragments and fines are due to either poor blast design or adverse geological conditions. It must be noted that only 20 to $30 \%$ of explosive energy is used to loosen and fragment the rock. From the rest of the energy, a major percentage is wasted in the form of flyrock, ground vibration, air over-pressure, generation of dust and excessive fines etc. (Singh and Singh, 2005; Rezaei et al., 2011; Hajihassani et al., 2014; Sadeghi et al., 2020).

In the current scenario, as the mining operations are increasing in areas close to human settlements, various aforestated blasting nuisances call for emergent attention. Unless the blasting impediments such as fly rocks ground vibration, dust generation, and air overpressure, etc. are controlled, the problems are likely to grow out of proportion and not only create the unceasing urban sprawl in the vicinity of blasting sites, but also beyond that and would have a far-reaching impact on damage to the ecosystem. Therefore, any surface mining operation must critically address to the mitigation of blasting nuisances for reducing the unwarranted damage to the ecosystem on one hand, while complying to the safety and productivity requirements on the other hand (Kulekci et al., 2018).

Many researchers have attempted to predict nuisances due to blasting through various empirical equations (Kulekci and Yilmaz, 2018; 2019). However, the performance of these models has not been very satisfactory in the field scale owing to lack of precision and scientifically. With the advent of scientific tools, techniques and gadgets (both hardware and software) in the past few decades it is possible to improve the accuracy and precision of prediction (Alemdag et al., 2019). To this end, the use of AI techniques including training and testing of blast data and comparing the results using different computational algorithms, have gained tremendous significance in last almost one decade.

The AI techniques such as fuzzy inference system (FIS), artificial neural network (ANN), and adaptive neuro-fuzzy inference system (ANFIS) have already been successfully deployed in solving complex geotechnical problems (e.g., Momeni et al., 2014; Mohamad et al.; 2013a). These methods have also been extensively utilized for mitigation of blasting nuisances (e.g., Monjezi and Dehghani, 2008; Esmaeili et al., 2014) as the AI-based analytical models take benefit of flexible nature of data due to which, the models 
can be easily calibrated as a prognostic tool for any new data that is obtained. This benefit makes the AI a fast and powerful tool in resolving the problems the relationship between the input and output parameters are nonlinear and are not known (Garret, 1994).

In this light, the present paper provides a comprehensive review of some predictive models that have been widely used by focussing on prediction the flyrock distance due to blasting. Since flyrocks are very detrimental for any blasting episode and may call a lot of wrath not only within but also outside the mine boundaries. Furthermore, the paper is especially focussing on flyrocks state-of-art since this subject area needs as much importance as the ground vibration, air over pressure and dust, the paper aims at providing review of various models that can predict the flyrock distance effectively before the blast. This will help in improving the blast design thereby minimizing and controlling the flyrock distance.

\section{Materials and Methods}

\subsection{Mechanisms of Flyrock}

\subsubsection{Rifling}

Rifling occurs due to improper stemming and stemming material. The gaseous product of detonation can escape rapidly from the blasthole along the least resistance path resulting in ejection of stemming material and collar rock leading to flyrock (Figure 1). The disproportionate rocks in the stemming column may become lethal projectiles. Rifling can also be closely related to airblast mechanism (Amini et al., 2011; Ghasemi et al., 2012a).

\subsubsection{Cratering}

Cratering occurs mainly due to insufficient stemming length. It may also happen due to weak collar rock (Figure 1). The crater in the collar region due to weakened rock layer from the previous blast may result in flyrock which can be projected in any direction. The gaseous products of detonation start rapidly escaping through this region generating cratering and flyrock. Shorter inter-row delays or improper initiation of blasting rows may also lead to similar effects (Amini et al., 2011; Ghasemi et al., 2012a).

\subsubsection{Face Bursting}

Face bursting occurs due to reasons such as insufficient burden, overcharging in the zones of weakness or the regions with major geological structures (Figure 1). The escape of gaseous detonation products at high pressure from these zones results in airblast, noise and flyrock (Amini et al., 2011; Ghasemi et al., 2012a).

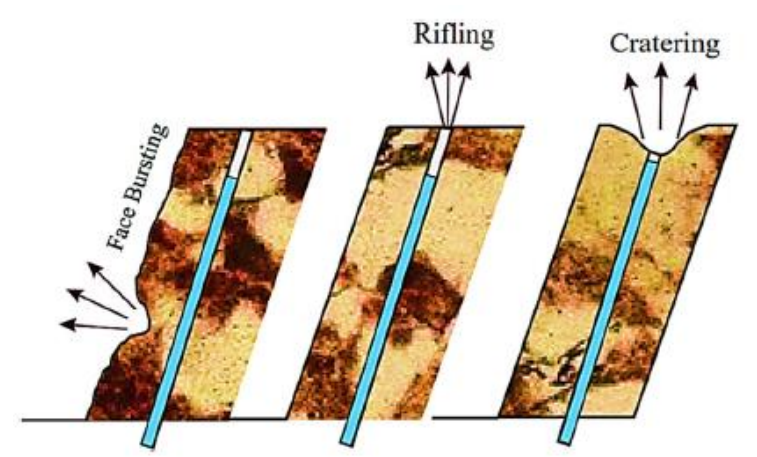

Figure 1. Mechanisms of flyrock-face burst, cratering and rifling (Zhou et al., 2019)

\subsection{Causes of Flyrock}

Flyrock is unexpected projection of rock fragments due to blasting beyond blast area. The area in which person may get injured due to blasting is generally referred as a blast area. The extent of blast area depends on rock mass properties, geology, blast design parameters, and the properties of the explosive used. The major reasons for cause of flyrock are the mismatch between explosive energy with the physicomechanical properties of the rock. The improper blast designs also contribute to this in a prodigious manner (Bajpayee et al., 2004, Mishra and Rout, 2011; Murlidhar et al., 2020).

\subsection{Theory of Flyrock Generation}

In any blasting operation, flyrock is one of the unwanted phenomena which may cause nuisances. This includes disproportionately propelled rock fragments that are energized even to cross the mine boundaries endangering the 
safety of man, materials, and machines. In a milder version they have abilities to cross the specified danger zone within the mining area also with similar consequences (IME, 1997). Flyrock can consequence in fatalities, injuries to human and other stray animals, and permanent damage to machineries, nearby structures, and other installations. Various studies have led towards a better understanding of causes of flyrock and helped in identifying the parameters responsible for the generation of flyrocks (Lundborg et al., 1975; Verakis and Lobb, 2003).

Some of the major parameters responsible for flyrock as explained by various studies are inappropriate delay time, improper blasthole pattern, insufficient burden, excessive charging, hole diameter, misfires, rock mass properties, geological structures, geological anomalies, and inadequate stemming, (Langefors and Kishlstrom, 1963; Holmeberg and Persson, 1976; Roth, 1979; Persson et al., 1994; Adhikari, 1999; Kecojevic and Radomsky, 2005; Mohamad et al., 2013b; Mohamad et al., 2018). Lundborg (1974,1981) developed an empirical model for prediction of flyrock. Studies on the flyrock due to blasting were also accomplished by Ladegaard and Persson (1973), Fletcher and Andrea (1986), Siskind and Kopp (1995), Shea and Clark (1998), Bajpayee et al. (2004), Rehak et al. (2001), Jang and Topal (2014), Armaghani et. al. (2015a), Koopialipoor et al. (2019) and Yan et. al. (2020).

\section{Results}

It is important to identify and demarcate danger zones to avoid hazards associated with flyrock. Security lapses, lack of knowledge, and poor competence in judging the flyrock are aminly responsible for Accidents due to flyrocks (Adhikari, 1999; Bajpayee et al. 2004; Raina et al. 2011). To overcome the incompetence in prejudging the flyrock distance, various models have been developed using Fuzzy Inference System (FIS), Adaptive Neuro-Fuzzy Inference System (ANFIS), Artificial Neural Network (ANN), ANN based Imperialism Competitive Algorithm (ICA), ANN based Particle Swarm
Optimization (PSO), and Support Vector Machine (SVM) to predict the flyrock distances in any blasting round.

\subsection{Prediction of Flyrock by Fuzzy Inference System}

Rezaei et al. (2011) developed a fuzzy model to study flyrock phenomenon in the blasting. Spacing, burden, hole depth, stemming length, and powder factor were considered as input parameters. A comparative evaluation between the performance of fuzzy model and conventional statistical method was also performed. Coefficient of determination (R2) for the fuzzy model and conventional statistical model were 0.984 and 0.701 , respectively whereas the root mean square error (RMSE) for the fuzzy model and conventional statistical model were found as 1.98 and 8.31 , respectively. As such, the fuzzy based model was reported to be superior over the statistical model. The study also performed sensitivity analysis which revealed that the most effective parameters on the flyrock were the powder factor and stemming length whereas the least effective was rock density.

Same testing datasets were used for both fuzzy model and statistical model in order to compare the performance. The graph of predicted vs measured flyrock distance for fuzzy and statistical models developed by Rezaei et al. (2011) are shown in Figure 2, respectively. The predictive capability of both fuzzy model and statistical model is shown in the Figure 3. It can be observed from the figures below that the performance of the fuzzy is much better compared to conventional statistical model in terms of R2.

Armaghani et al. (2015b) developed two models using ANFIS and ANN to predict flyrock distance. Powder factor and maximum charge per delay were used as input parameters to predict flyrock distance. The study indicated that the ANFIS $(R 2=0.964)$ technique can provide better prediction capacity for flyrock distance when compared to ANN $(\mathrm{R} 2=0.925)$ model. The $\mathrm{R} 2$ for measured and predicted values for ANFIS and ANN are presented in Figure 4. 

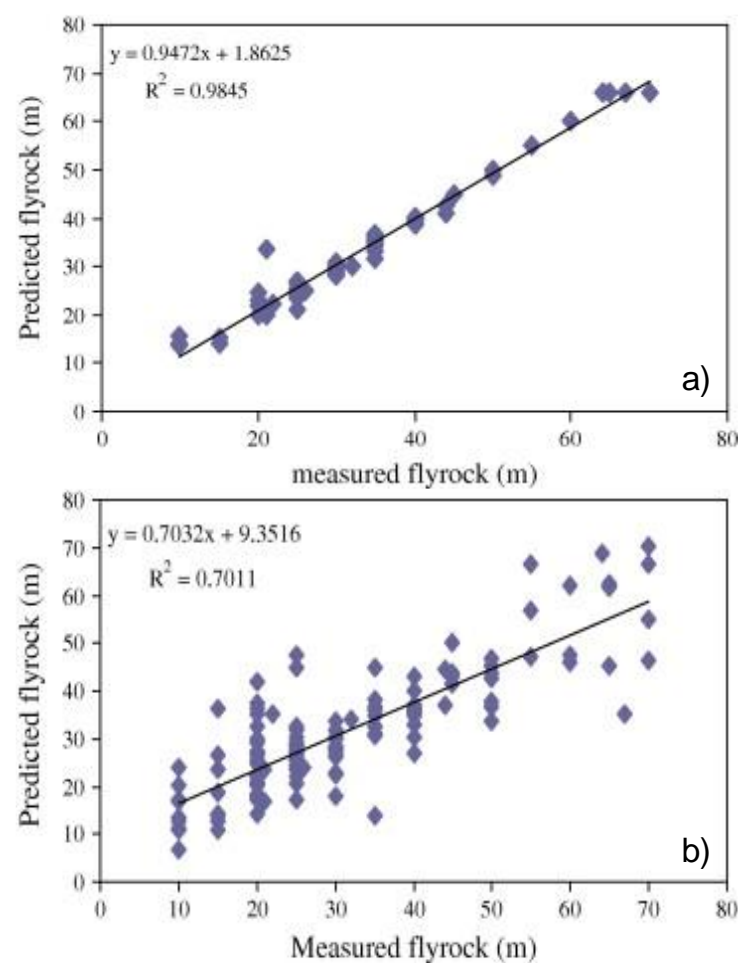

Figure 2. Comparative evaluation of measured and predicted flyrock distances for the (a) fuzzy model and (b) statistical model (Rezaei et al., 2011)

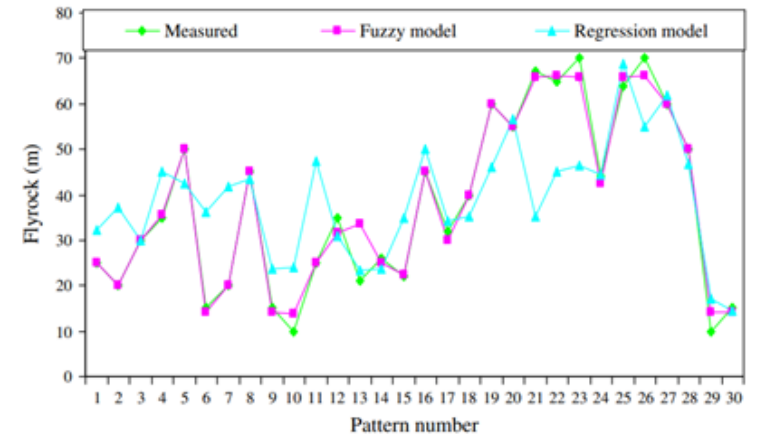

Figure 3. Comparison evaluation of predicted and measured flyrock distances (Rezaei et al., 2011)
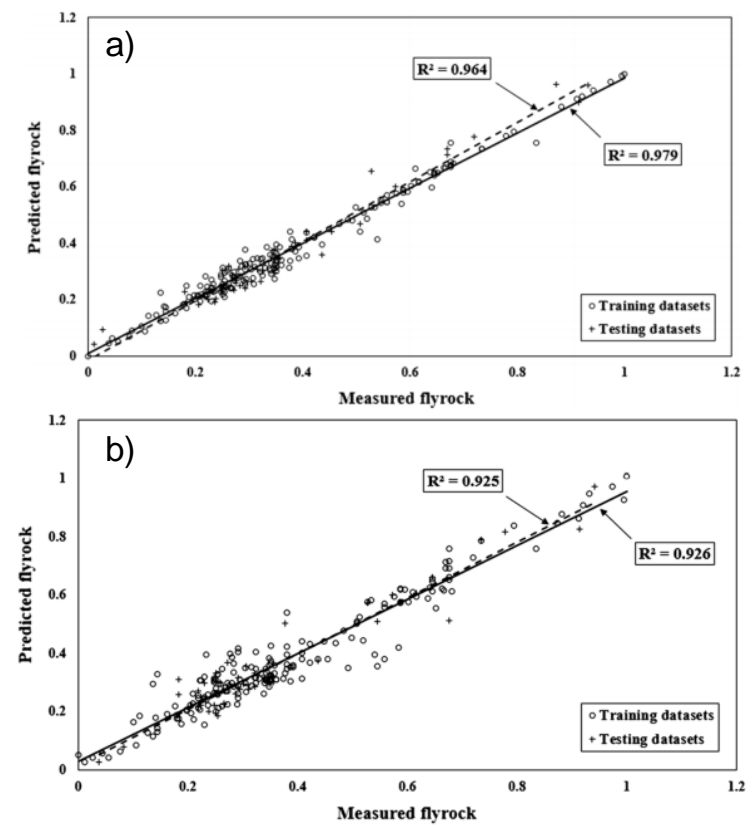

Figure 4. $\mathrm{R}^{2}$ of measured and predicted values of flyrock for (a) ANFIS and (b) ANN (Armaghani et al., 2015a)

\subsection{Prediction of Fly-rock by Artificial Neural Network (ANN)}

Monjezi et al. (2010a) employed Neuro-Genetic Algorithm (NGA) based modelling for predicting flyrock distances. The neural network parameters were optimized using Genetic Algorithm. Spacing, burden, powder factor, stemming length, and charge per delay were used as input parameters to predict the flyrock distances. The performance of the model was also compared with statistical method. Better efficiency was observed in Neuro-Genetic Algorithm with a high R2 value of 0.976 between predicted and measured flyrock. Stemming and powder factor were reported as the most influential parameters for predicting flyrock whereas RMR, spacing, and specific drilling, were the least effective parameters for predicting flyrock. 


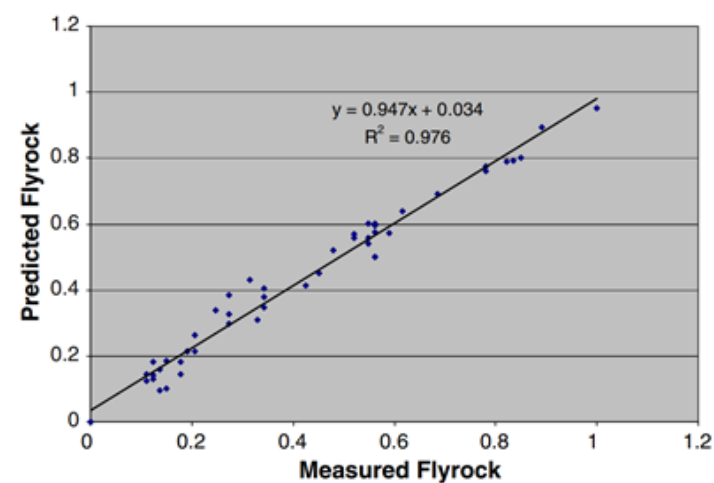

Figure 5. Correlation between predicted and measured flyrock for NGA (Monjezi et al., 2010a)

Monjezi et al. (2010b) developed a back propagation ANN model to predict flyrock occurrence and their distances. Hole diameter, average hole depth, stemming length, burden to spacing ratio, number of rows, powder factor, charge per delay, and rock density were used as input parameters for developing the model. The study determined ANN as a useful technique for improving the efficiency of blasting. It also reported a reduction from $110 \mathrm{~m}$ to $30 \mathrm{~m}$ in flyrock distance. A comparison of measured and predicted flyrock is shown in Figure 6.

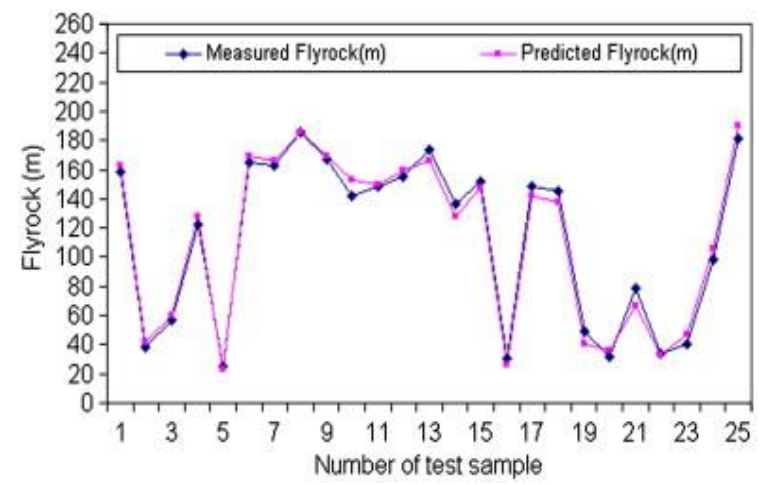

Figure 6. Comparison of measured and predicted flyrock distance (Monjezi et al., 2010b)

Monjezi et al. (2012) used ANN to predict the flyrock in the blasting operation. Burden, spacing, stemming, hole depth, hole diameter, charge per delay, powder factor, and specific drilling, RMR were used as input parameters. It was reported in the study that that ANN has advantage in predicting flyrock in comparison to statistical model and Lundborg et al. (1975) model. Also, sensitivity analysis revealed that stemming, powder factor, charge per delay, and hole diameter were the most effective parameters, whereas hole depth and specific drilling were reported as the least effective parameters in this regard. Figure 7 presents a comparison between measured and predicted flyrock values by various models. As presented in the figure, the results of Lundborg equations have high predicted values of flyrock compared to measured values. Moreover, the results of ANN were reported as more accurate as compared to Lundborg model and statistical model.

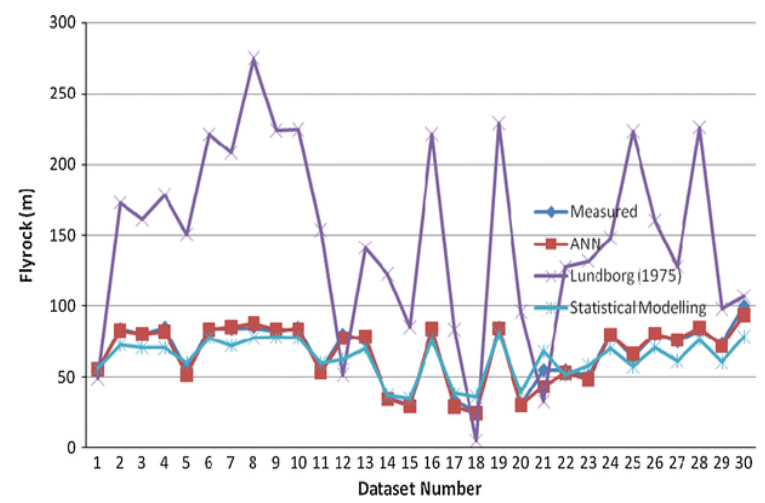

Figure 7. Comparative evaluation of measured and predicted flyrock by different models (Monjezi et al., 2012)

Ghasemi (2012b) proposed two modes: the ANN based on backpropagation algorithm and the fuzzy model based on Mamdani algorithm. Burden, spacing, hole length, stemming, charge per delay, and powder factor were used as input parameters. The research reported fuzzy model as more reliable and successful than the ANN model. The R2 was determined as 0.957 for the fuzzy model. The deviation interval for fussy model $(-8$ to +9$)$ were found smaller than that of ANN model (-10 to 18). The predicted flyrock distances by fussy method were also found closer to the measured value of flyrock distance than that of ANN based model. 


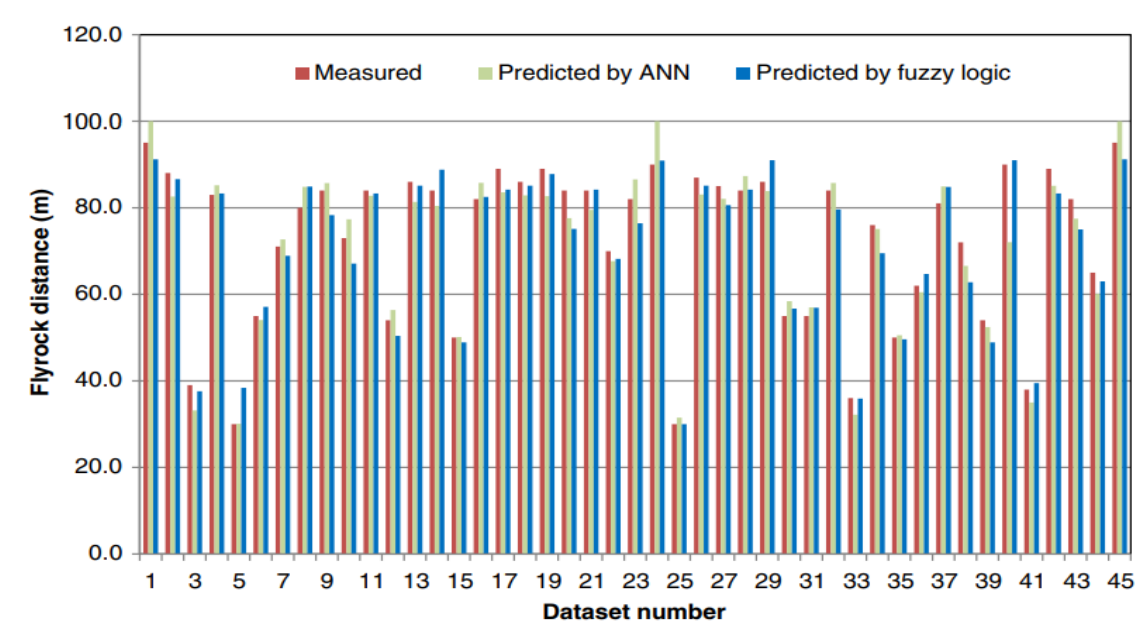

Figure 8. Comparison between the measured and predicted flyrock for fussy model and ANN model (Ghasemi, 2012b)

Mohamad et al. (2013a) introduced a backpropagation ANN model to predict the size of fllyrock and the flyrock distance. The trial-anderror method is used to determine the best suited architecture of ANN. Hole depth, hole diameter, burden to spacing ratio, stemming, subdrilling, number of rows, charge per delay, powder factor, and rock density were used as input parameters. Adequate consistency was observed between the predicted results and the measured data. The correlation coefficient for training, validation, and testing was obtained for evaluation of performance of the selected network. Figure 9 shows the linear regression analysis for the measured values and predicted values obtained by the developed ANN model. The analysis indicated a high value of correlation coefficient among measured and predicted values.

Trivedi et al. (2014) predicted flyrock distances by ANN, and MVRA. The motion analysis of videos of flyrock projectiles were also used to calculate flyrock distance and compared it with the observed data. Linear charge concentration, stemming length, burden, specific charge, RQD, and UCS were selected as input parameters. ANN method was reported as having the highest coefficient of determination and lowest Mean absolute error as well as root mean square error. The specific charge and linear charge concentration were positively correlated with the flyrock distance, whereas stemming length, burden, RQD and UCS have a negative correlation with the flyrock distance. Burden and stemming length have most pronounced impact for blast hole of $165 \mathrm{~mm}$ whereas UCS and RQD have most pronounced impact for blast hole of $115 \mathrm{~mm}$. Figure 10 presents a comparison between predicted, calculated and observed flyrock distances.
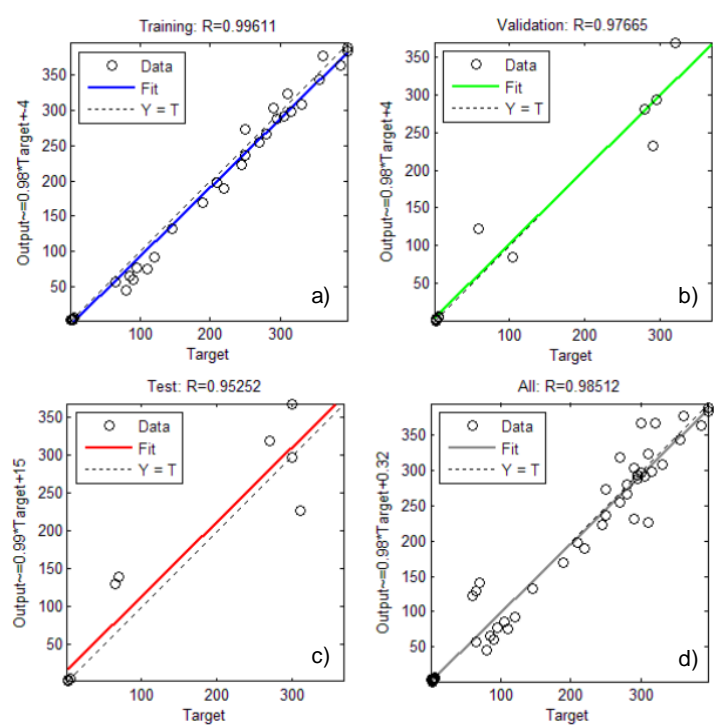

Figure 9. Linear regression analysis for the selected model for datasets (a) training, (b) validation, (c) testing and (d) all (Mohamad et al., 2013a) 


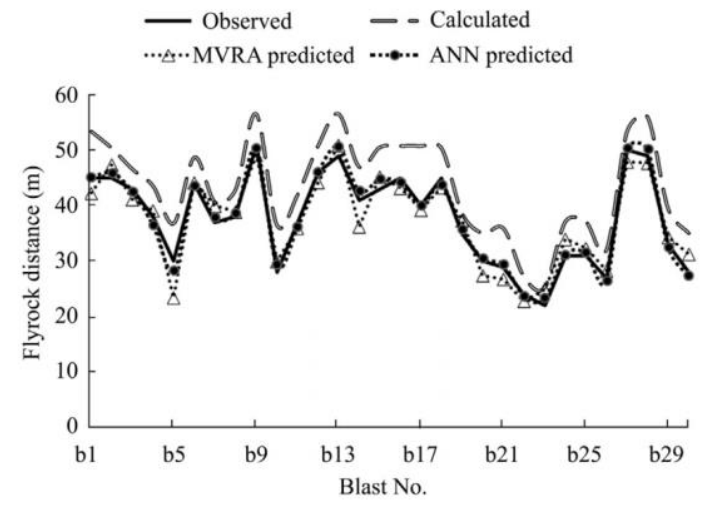

Figure 10. Comparison between predicted, calculated and observed flyrock distances (Trivedi et al., 2014)

Saghatforoush et al. (2015) employed ANN to predict the flyrock distance. It selected powder factor, spacing, burden, stemming, and depth of hole as input parameters. The value of determination coefficient for the ANN model was 0.994, indicating high performance capacity of ANN in predicting flyrock distance (Figure 11). Ant Colony Optimization (ACO) algorithm is used in this study for optimizing the blasting parameters as well as outputs of ANN part. Trialand-error method is used for determining the number of iterations and values of ACO parameters. The study reported a reduction of $61 \%$ for flyrock distance.

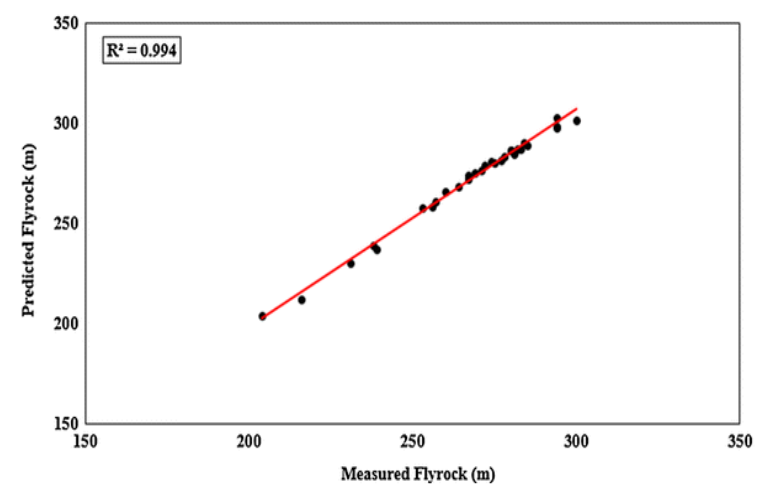

Figure 11. Evaulation of measured and predicted values of flyrock for ANN model (Saghatforoush et al., 2015)

Rad et al. (2020) used ANN to predict blastinduced flyrock. Burden, spacing, stemming length and maximum charge per delay were considered as the input parameters. The study found that the performance of ANN was not good enough. The performance of ANN was then improved by using Genetic algorithm (GA). The GA-ANN was found superior when compared to ANN and regression models. Moreover, a combination of recurrent fuzzy neural network (RFNN) and GA hybrid model was also developed. The performance of RFNN-GA model was reported to be better than the ANN and GAANN models.

The study also conducted sensitivity analysis. This analysis revealed that the maximum charge per delay was the most influencing parameter affecting flyrock than the other parameters. RMSE and R2 were used for performance analysis of the predictive models proposed in this study. It is observed that the by the RFNN-GA model had lowest RMSE and the highest R2 values, for testing datasets. The regression plots between the predicted results obtained from the predictive models and the real datasets for testing datasets are presented in Fig 12. From these figures, the superior predictive ability of RFNNGA model than the GA-ANN, ANN, and nonlinear regression models can be observed.

\subsection{Prediction of Fly-rock by Imperialism Competitive Algorithm (ICA)}

Marto et al. (2014) developed a combination of imperialist competitive algorithm (ICA) and ANN based model to predict flyrock distances due to blasting operation. Hole depth, stemming length, maximum charge per delay, burden to spacing ratio, powder factor, Schmidt hammer rebound number, and rock density were used as input parameters. The study demonstrated high degree of accuracy to predict flyrock distance with the proposed ICA-ANN model. The study reported maximum charge per delay and powder factor as the most influential parameters affecting flyrock. In this study, models were developed using ICAANN and MRA to predict flyrock distance. Burden to spacing, hole depth, stemming, powder factor, maximum charge per delay, Schmidt hammer rebound number, and rock density were used as input parameter. Figure 13 presents the graphs between predicted flyrock distances using ICA-ANN and MRA techniques against the measured flyrock distances respectively. 

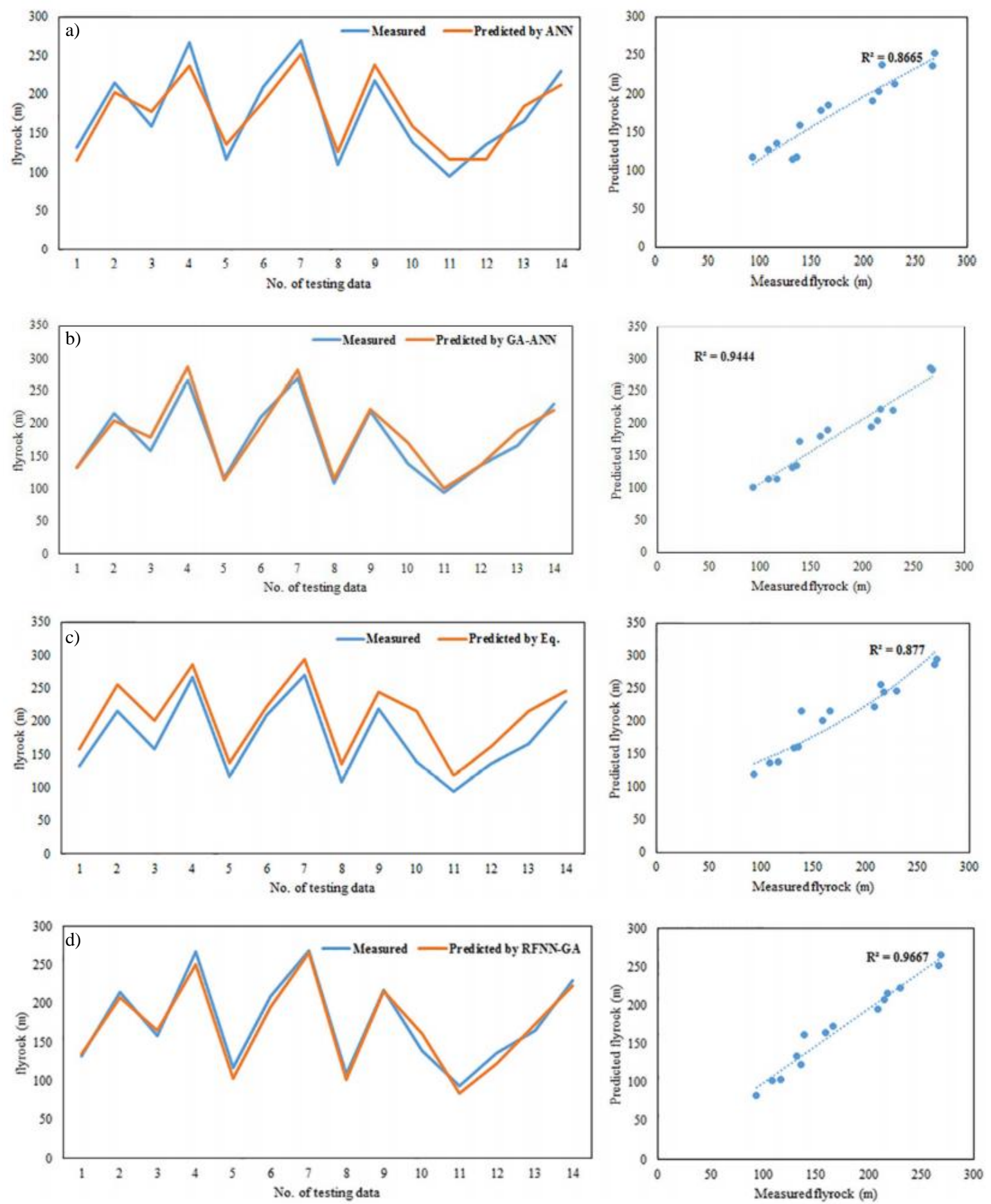

Figure 12. Results of simulation of flyrock using (a) ANN, (b) GA-ANN, (c) nonlinear regression and (d) RFNN-GA (Rad et al., 2020)

The predictive model indices are tabulated in Table 1. It is evident that the proposed ICA-ANN model produced higher performance in predicting flyrock distance among all methods. 

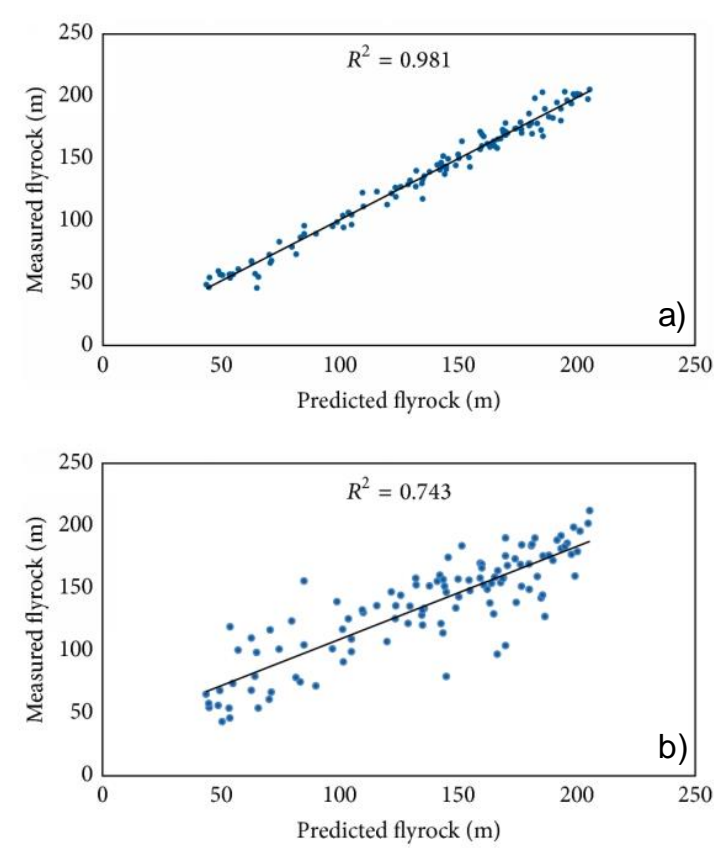

Figure 13. R2 of model in predicting flyrock distance (a) ICA-ANN and (b) MRA (Marto et al., 2014)

Table 1. Performance indices of the various predictive models (Marto et al.,2014)

\begin{tabular}{lcc}
\hline $\begin{array}{l}\text { Predictive } \\
\text { model }\end{array}$ & $\begin{array}{c}\text { Performance } \\
\text { indices }\left(\mathrm{R}^{2}\right)\end{array}$ & RMSE \\
\hline ICA-ANN & 0.981 & 6.582 \\
BP-ANN & 0.919 & 13.478 \\
MRA & 0.743 & 23.877 \\
Empirical & 0.118 & 109.064 \\
\hline
\end{tabular}

\subsection{Prediction of Fly-rock by Particle Swarm Optimization (PSO)}

Armaghani et al. (2013) employed a hybrid PSO based ANN model for prediction of flyrock distances. Hole diameter, hole depth, sub-drilling, stemming, spacing, burden, powder factor, charge per delay, number of rows, and rock density were used as input parameters. Optimum parameters of the PSO algorithm were obtained by sensitivity analysis. It was found that this network was able to accurately estimate the flyrock distance. It was also found that the powder factor and charge per delay were most effective parameters affecting the flyrock distance. Figure 19 shows the strengths of the relations (rij values) between input and outputs (flyrock distance and PPV) parameters.
Sensitivity analysis results show that powder factor and charge per delay are the most influential parameters on flyrock distance, whereas sub-drilling (I) and charge per delay are the most effective parameters on PPV.

\subsection{Prediction of Fly-rock by Support Vector Machine (SVM)}

Amini et al. (2011) demonstrated the application of SVM technique and ANN technique for prediction of flyrocks distances. Input parameters such as hole depth, hole diameter, spacing, burden, stemming, specific drilling and powder factor were considered for both the methods. It was reported that the running time considerably faster in SVM than ANNs. The accuracy of SVM model was also found to be higher than ANN based model.
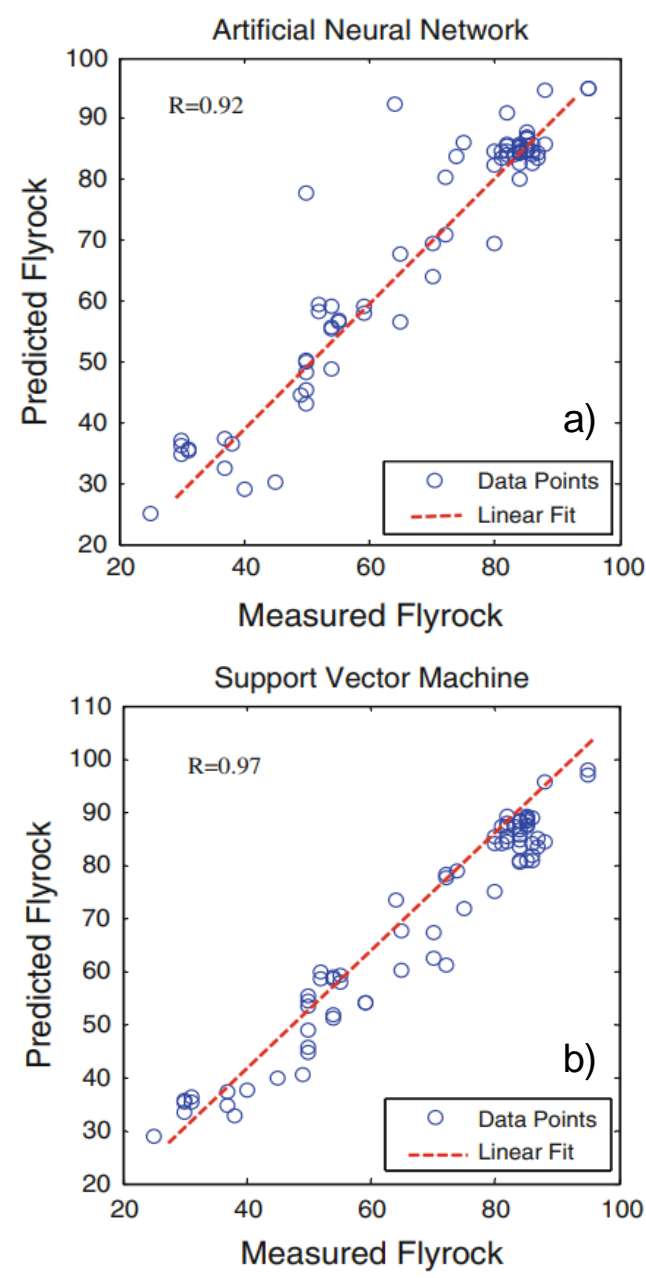

Figure 14. Correlation between measured and predicted flyrock by (a) ANN and (b) SVM techniques (Amini et al., 2011) 
The plot for SVM modelling indicated an acceptable correlation coefficient of $\mathrm{R}=0.97$ for prediction the flyrock. Moreover, it was depicted in Figure 14 that in situations where there is nonuniformly distributed dataset, the SVM is a more applicable model than ANN. For comparative evaluation the relative RMSE of both SVM and ANN was also determined. RMSE of SVM was 4.5 while that for the ANN is 7.98. It was also reported that, the SVM method consumed a considerably less time compared to that of the ANN methods in the prediction process. The study concluded that SVM had high performance and makes good prediction. However, it was also reported that ANN can be considered as an alternative approach after the SVM for the prediction of flyrock.

Manoj and Monjezi (2013) used the SVM model to predict the flyrock distance and occurrence in the blasting operations. Spacing, burden, hole length, stemming, specific drilling, and powder factor were used as input parameters. The SVM technique was reported as much better and more accurate in comparison with the statistical techniques. The SVM model had also a better prediction capacity for flyrock when compared to multivariate regression analysis (MVRA) model. The SRM model had it resulted in higher coefficient of determination and lesser mean absolute error (MAE). Figure 15 shows a graph of measured and predicted flyrock by SVM and MVRA. The SVM model demonstrated superiority over MVRA model.

Bhagat et al. (2021) used Classification and Regression Trees (CART) and Multiple linear regression (MLR) models for mitigation of flyrock during boulder blasting. Sensitivity analysis of selected input parameters in model was also carried out to find the relevancy in prediction of flyrock. Five inputs namely specific drill density, rock density, charge per hole, specific charge, and stemming to burden ratio were considered for the best models. The RMSE and R2 values of testing dataset of CART model were 1.141 and 0.9555 respectively, whereas for the MLR model, they were 4.868 and 0.7938 respectively.

The CART model was reported to be the better model compared to MLR for predicting fly-rock distance. The relevancy factor analysis of inputs revealed most contributing parameters in order of relevance as specific charge (0.935), specific drill density (0.847), charge per hole (0.583), stemming to burden ratio $(0.383)$ and rock density (0.243). Comparison of measured and predicted fly-rock distances for CART and MLR model is shown in Figure 16.

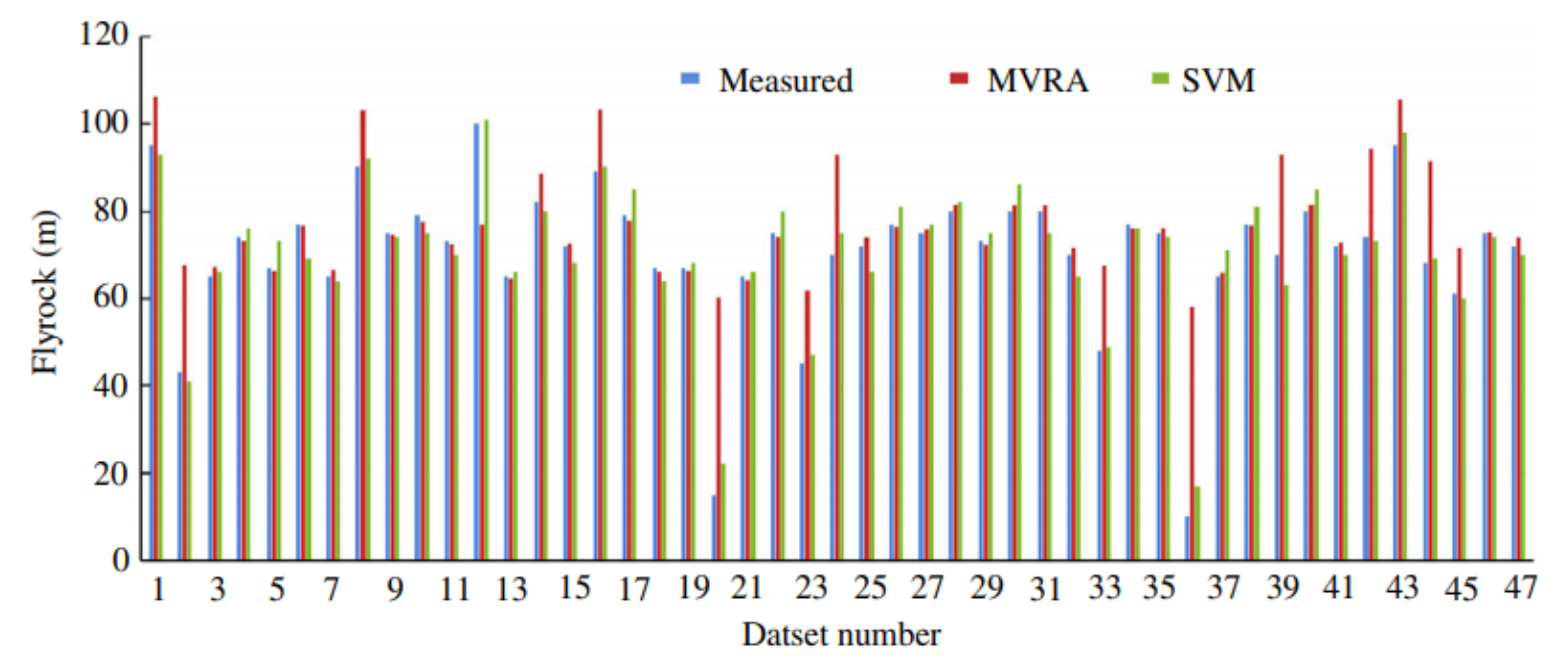

Figure 15. Comparison of measured and predicted flyrock distance by SVM and MVRA (Manoj and Monjezi, 2013) 


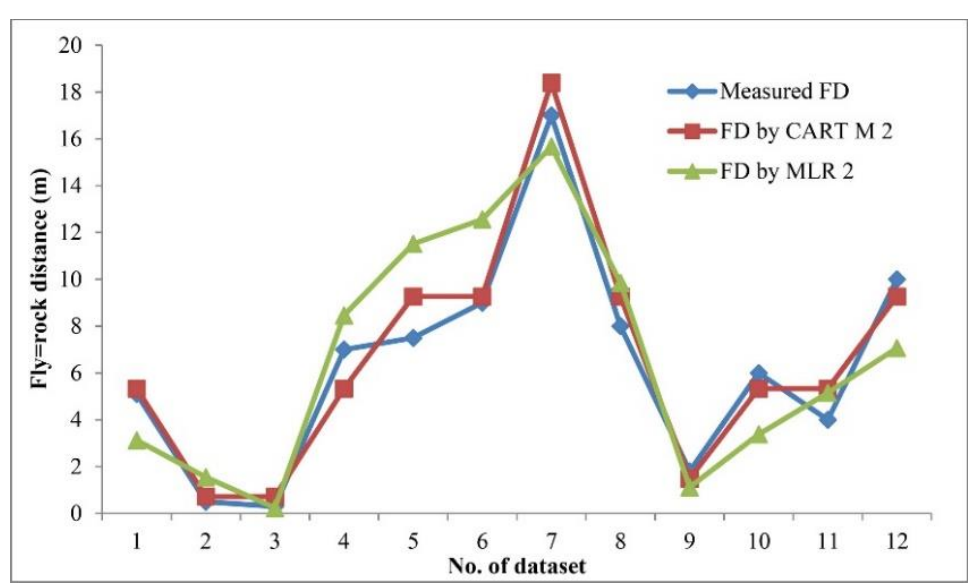

Figure 16. Comparison of measured and predicted fly-rock distances by best CART and MLR models

\section{Discussion}

It is well understood that three important parameters which affect the blasting design, and its outcome are rock mass parameters, blast design parameters, and explosive parameters.

Nevertheless, most of the models for predicting the occurrence and distance of flyrocks have largely included the blast design parameters namely, spacing, burden, hole diameter, spacing to burden ratio, stemming length, hole depth, and subgrade drilling.

Burden or burden to spacing ratio were used as input parameters in all the models. Burden has an important role in prediction of flyrock distance as the flyrock distance generally varies inversely to the burden. Flyrock distance seems to be directly proportional to the hole depth whereas it is inversely proportional to stemming length. Nonetheless, delay timing and initiation system (DF, NONEL, Electronic) play a significant impact on the flyrock, which needs to be thoroughly analysed by various state-of-art tools.

Among rock mass properties, rock density is the most common parameter used in the models. Rock density also has an important role in the prediction of flyrock distance. The lighter the rock, the greater is the distance that the rock may cover. Some of the models have also considered RMR and SMR. The RMR and SMR values can be a good indicator of geological conditions of the rock which can improve the prediction efficiency. Nevertheless, the geological discontinuities, hydrological properties and porosity are also some important parameters that need to be incorporated discreetly in future studies.

Maximum charge per delay, powder factor, and specific charge are the parameters related to the explosives that are used in the models. Maximum charge per delay represents the maximum quantity of explosive detonated at a given time indicated the maximum energy release, whereas the powder factor shows overall explosive energy release per unit volume of rock. Both factors play a crucial role on the assessment of flyrock distance. The index like blast ability index can also be incorporated for improving the prediction accuracy. Future studies need to lay additional emphasis on type of explosive, VOD of explosive and essentially on the explosive rock-matching as important study parameters.

\section{Conclusion}

From the foregoing paper it may be clearly drawn that flyrocks are a major source of nuisance in any blasting operation in surface mine. The occurrence of flyrocks due to blasting has certainly gained tremendous attention by recent researchers as well as mine operators since time immemorial. The soft computing techniques have contributed profoundly during the last decade in prognosis, control, and mitigation of flyrocks. However, at the same time it may be noted that the range of applicability of various models developed so far seems to be limited by the unscientific selection of input data, which, in turn, 
must be constraining factor in the prognosis and mitigation. Therefore, outside of the trained range the models may lack accuracy and precision. Therefore, it appears that the need of the hour is to use the AI based soft computing tools in prediction and mitigation of flyrock occurrence and distances based on thorough and scientific discretion of the input parameters to train test and validate the results. A lot more endeavour needs to be channelized in scientific identification of important rock mass, explosive and blasting design parameters to expand the scope of acceptance of prediction of flyrock occurrence, control, and mitigation. This will eliminate the subjectivity in selection of the input parameters in the prediction models.

\section{References}

Adhikari, G.R. (1999). Studies on flyrock at limestone quarries. Rock Mechanics and Rock Engineering, 32(4), 291-301.

Alemdag, S., Zeybek, H.I., Kulekci, G. (2019). Stability evaluation of the Gümüşhane-Akçakale Cave by numerical analysis method. Journal of Mountain Science, 16(9), 2150-58.

Amini, H., Gholami, R., Monjezi, M., Torabi, S.R., Zadhesh, J. (2011). Evaluation of flyrock phenomenon due to blasting operation by support vector machine. Neural Computing and Applications, 21(8), 2077-2085.

Armaghani, D.J., Hajihassani, M., Mohamad, E.T., Marto, A., Noorani, S.A. (2013). Blasting-induced flyrock and ground vibration prediction through an expert artificial neural network based on particle swarm optimization. Arabian Journal of Geosciences, 7(12), 5383-5396.

Armaghani, D.J., Hajihassani, M., Monjezi, M., Mohamad, E.T., Marto, A., Moghaddam, M.R. (2015a). Application of two intelligent systems in predicting environmental impacts of quarry blasting. Arabian Journal of Geosciences, 8(11), 9647-9665.

Armaghani, D.J., Mohamad, E.T., Hajihassani, M., Alavi Nezhad Khalil Abad, S.V., Marto, A., Moghaddam, M.R. (2015b). Evaluation and prediction of flyrock resulting from blasting operations using empirical and computational methods. Engineering with Computers, 32(1), 109-121.
Bajpayee, T.S., Rehak, T.R., Mowrey, G.L., Ingram, D.K. (2004). Blasting injuries in surface mining with emphasis on flyrock and blast area security. Journal of Safety Research, 35(1), 47-57.

Bhagat, N.K., Rana, A., Mishra, A.K., Singh, M.M., Singh, A., Singh, P.K. (2021). Prediction of flyrock during boulder blasting on infrastructure slopes using CART technique. Geomatics, Natural Hazards and Risk, 12(1), 1715-1740.

Esmaeili, M., Osanloo, M., Rashidinejad, F., Bazzazi, A.A., Taji, M. (2014). Multiple regression, ANN and ANFIS models for prediction of backbreak in the open pit blasting. Engineering with Computers, 30(4), 549-558.

Fletcher, L.R., Andrea, D.V. (1986). Control of flyrock in blasting. In: Proceedings of the 12th Annual Conference on Explosives and Blasting Technique, Cleveland, USA, 167-177.

Garret, J.H. (1994). Where and why artificial neural networks are applicable in civil engineering. Journal of Computer in Civil Engineering, 8, 129130

Ghasemi, E., Sari, M., Ataei, M. (2012a). Development of an empirical model for predicting the effects of controllable blasting parameters on flyrock distance in surface mines. International Journal of Rock Mechanics and Mining Sciences, 52, 163-170.

Ghasemi, E., Amini, H., Ataei, M., Khalokakaei, R. (2012b). Application of artificial intelligence techniques for predicting the flyrock distance caused by blasting operation. Arabian Journal of Geosciences, 7(1), 193-202.

Gorgulu, K., Arpaz, E., Uysal, O., Duruturk, Y.S., Yuksek, A.G., Kocaslan, A., Dilmac, M.K. (2015). Investigation of the effects of blasting design parameters and rock properties on blast-induced ground vibrations. Arabian Journal of Geosciences, 8(6), 4269- 4278.

Hajihassani, M., Armaghani, D.J., Sohaei, H., Mohamad, E.T., Marto, A. (2014). Prediction of airblast-overpressure induced by blasting using a hybrid artificial neural network and particle swarm optimization. Applied Acoustics, 80, 57-67.

Holmeberg, R., Persson, G. (1976). The effect of stemming on the distance of throw of flyrock in connection with hole diameters. Swedish Detonic Research Foundation, Report DS, 1.

Institute of Makers of Explosives (IME), (1997). 
Glossary of commercial explosives industry terms. Safety publication, Institute of Makers of Explosives, Washington, 12.

Jang, H., Topal. E. (2014). A review of soft computing technology applications in several mining problems. Applied Soft Computing, 22, 638-651.

Kahriman, A., Ozer, U., Aksoy, M., Karadogan, A., Tuncer, G. (2006). Environmental impacts of bench blasting at Hisarcik Boron open pit mine in Turkey. Environmental Geology, 50 (7), 1015-1023.

Karadogan, A., Kahriman, A., Ozer, U. (2014). A new damage criteria norm for blast induced ground vibrations in Turkey. Arabian Journal of Geosciences, 7(4), 1617-1627.

Kecojevic, V., Radomsky, M. (2005). Flyrock phenomena and area security in blasting-related accidents. Safety Science, 43(9), 739-750.

Koopialipoor, M., Fallah, A., Armaghani, D. Azizi, A., Mohamad, E. (2019). Three hybrid intelligent models in estimating flyrock distance resulting from blasting. Engineering with Computers, 35, 243-256.

Kulekci, G., Alemdag, S. (2016). The investigation of blasting effect on natural heritages in quarries: Registered rock room sample. Proceedings of the 8th International Aggregates Symposium, 13-14 October, Kutahya, Turkey, 498-504.

Kulekci, G., Cullu, M., Yilmaz, A.O. (2018). Environmental problems to be created in mining procedures and measures to be taken; quarry an example of dust emissions. EurAsia Waste Management Symposium, 319-27.

Kulekci, G., Yilmaz, A.O. (2018). Roadway tunnel construction with drilling-blasting method; Gümüşhane environment road example. Int. Journal on Mathematic, Engineering and Natural Sciences, 4, 34-39.

Kulekci, G., Yilmaz, A. (2019). Investigation of the effect of activities in a coper mine on historical works, an example of Gümüşhane Süleymaniye. Journal of Underground Resources, 16(8), 1-14.

Ladegaard-Pedersen, A., Persson, A. (1973). Flyrock in Blasting II, Experimental Investigation. Swedish Detonic Research Foundation, Report DS 13, Stockholm.

Langefors, U., Kishlstrom, B. (1963). The Modern Technique of Rock Blasting. John Wiley \& Sons, New York, USA.
Lundborg, N. (1974). The hazards of flyrock in rock blasting. Swedish Detonic Research Foundation, Reports DS 12, Stockholm.

Lundborg, N. (1981). Risk for flyrock when blasting. Swedish Council for Building Research, BFR Report R29, Stockholm.

Lundborg, N., Persson, A., Ladegaard-Pedersen, A., Holmberg, R. (1975). Keeping the lid on flyrock in open-pit blasting. Engineering and Mining Journal, 176, 95-100.

Manoj, K., Monjezi, M. (2013). Prediction of flyrock in open pit blasting operation using machine learning method. International Journal of Mining Science and Technology, 23(3), 313-316.

Marto, A., Hajihassani, M., Jahed Armaghani, D., Makhtar, A. (2014). A novel approach for blastinduced flyrock prediction based on imperialist competitive algorithm and artificial neural network. The Scientific World Journal, 1-11.

Mishra, A.K., Rout, M. (2011). Flyrocks - detection and mitigation at construction site in blasting operation. World Environment, 1(1), 1-5.

Mohamad, E.T., Armaghani, D.J., Hajihassani, M., Faizi, K., Marto, A. (2013a). A simulation approach to predict blasting-induced flyrock and size of thrown rocks. Electronic Journal of Geotechnical Engineering, 18, 365-374.

Mohamad, E.T., Armaghani, D.J., Motaghedi, H. (2013b). The effect of geological structure and powder factor in flyrock accident, Masai, Johor, Malaysia. Electronic Journal of Geotechnical Engineering, 18, 5561-5572.

Mohamad, E.T., Yi, C.S., Murlidhar, B.R., Saad, R. (2018). Effect of geological structure on flyrock prediction in construction blasting. Geotechnical and Geological Engineering, 36(4), 2217-2235.

Momeni, E., Nazir, R., Armaghani, D.J., Maizir, H. (2014). Prediction of pile bearing capacity using a hybrid genetic algorithm-based ANN. Measurement, 57, 122-131.

Monjezi, M., Amini Khoshalan, H., Yazdian Varjani, A. (2010a). Prediction of flyrock and backbreak in open pit blasting operation: a neuro-genetic approach. Arabian Journal of Geosciences, 5(3), 441-448.

Monjezi, M., Bahrami, A., Yazdian Varjani, A. (2010b). Simultaneous prediction of fragmentation and flyrock in blasting operation using artificial 
neural networks. International Journal of Rock Mechanics and Mining Sciences, 47(3), 476-480.

Monjezi, M., Dehghani, H. (2008). Evaluation of effect of blasting pattern parameters on back break using neural networks. International Journal of Rock Mechanics and Mining Sciences, 45(8), 1446-1453.

Monjezi, M., Mehrdanesh, A., Malek, A., Khandelwal, M. (2012). Evaluation of effect of blast design parameters on flyrock using artificial neural networks. Neural Computing and Applications, 23(2), 349-356.

Murlidhar, B., Kumar, D., Armaghani, D., Roy, B., Pham B.T. (2020). A novel intelligent ELM-BBO technique for predicting distance of mine blastinginduced flyrock. Natural Resources Research, 29(6), 4103-4120.

Persson, P.A., Holmberg, R., Lee, J., Coursen, D.L., Davis, W.C. (1994). Book review: rock blasting and explosives engineering. Journal of Energetic Materials, 12(1), 85-88.

Rad, H., Bakhshayeshi, I., Jusoh, W., Foong, L. (2020). Prediction of flyrock in mine blasting: a new computational intelligence approach. Natural Resources Research, 29(2), 609-623.

Raina, A.K., Chakraborty, A.K., Choudhury, P.B., Sinha, A. (2011). Flyrock danger zone demarcation in opencast mines: a risk based approach. Bulletin of Engineering Geology and the Environment, 70(1), 163-172.

Rehak, T.R., Bajpayee, T.S., Mowrey, G.L., Ingram, D.K. (2001). Flyrock issues in blasting. In: Proceedings of the 27th Annual Conference on Explosives and Blasting Technique, I. Cleveland, USA, 165-175.

Rezaei, M., Monjezi, M., Varjani, A.Y. (2011). Development of a fuzzy model to predict flyrock in surface mining. Safety Science, 49, 298-305.

Roth, J. (1979). A model for the determination of flyrock range as a function of shot conditions. Management Science Associates, Altos, USA.

Sadeghi, F., Monjezi, M., Armaghani, D.J. (2020). Evaluation and optimization of prediction of toe that arises from mine blasting operation using various soft computing techniques. Natural Resources Research, 29(2), 887-903.

Saghatforoush, A., Monjezi, M., Faradonbeh, R.S., Armaghani, D.J. (2015). Combination of neural network and ant colony optimization algorithms for prediction and optimization of flyrock and backbreak induced by blasting. Engineering with Computers, 32(2), 255-266.

Shea, C.W., Clark, D. (1998). Avoiding tragedy: lessons to be learned from a flyrock fatality. Coal Age, 103(2), 51-54.

Singh, T.N., Singh, V. (2005). An intelligent approach to prediction and control ground vibration in mines. Geotechnical and Geological Engineering, 23(3), 249-262.

Siskind, D.E., Kopp, J.W. (1995). Blasting accidents in mines: a 16-year summary. In: Proceedings of the 21 st Annual Conference on Explosives and Blasting Technique, Cleveland, USA, 224-239.

Trivedi, R., Singh, T.N., Raina, A.K. (2014). Prediction of blast-induced flyrock in Indian limestone mines using neural networks. Journal of Rock Mechanics and Geotechnical Engineering, 6(5), 447-454.

Uysal, O., Cavus, M. (2013). Effect of a pre-split plane on the frequencies of blast induced ground vibrations. Acta Montanistica Slovaca, 18(2), 101109.

Verakis H.C., Lobb T.E. (2003), An analysis of blasting accidents in mining operations. In: Proceedings of the 29th annual conference on explosives and blasting technique, Cleveland, USA, 119-129.

Yan, Yu., Hou, X., Fei, H. (2020). Review of predicting the blast-induced ground vibrations to reduce impacts on ambient urban communities. Journal of Cleaner Production, 260, 121135.

Zhou, J., Aghili, N., Ghaleini, E.N., Bui, D.T., Tahir, M.M., Koopialipoor, M. (2019). A Monte Carlo simulation approach for effective assessment of flyrock based on intelligent system of neural network. Engineering with Computers, 36(2), 713723. 